\title{
PRORAČUN KRANSKIH NOSAČA PREMA EUROKOD NORMAMA
}

\section{Mario Joketović}

Sveučilište J.J. Strossmayera u Osijeku, Građevinski fakultet Osijek, student

\section{Ivan Radić}

Sveučilište J.J. Strossmayera u Osijeku, Građevinski fakultet Osijek, dipl.ing.građ.

\section{Damir Markulak}

Sveučilište J.J. Strossmayera u Osijeku, Građevinski fakultet Osijek, prof.dr.sc.

Sažetak: U radu se opisuje način modeliranja opterećenja zbog djelovanja kranova prema Eurokod normama HRN EN 1991-3:2006. Taj se postupak svojom složenošću i preciznošću u izračunu djelovanja bitno razlikuje od dosadašnjih načina proračuna. Na numeričkom primjeru industrijske hale $s$ kranom ilustriran je kodificirani način proračuna ovakvih konstrukcija prema Eurokod normama.

Ključne riječi: kranski nosač, modeliranje opterećenja, proračun, Eurokod

\section{DESIGN OF CRANE GIRDERS ACCORDING TO EUROCODE STANDARDS}

\begin{abstract}
This work describes a method of modeling the action of the load of cranes by Eurocode standards HRN EN 1991-3:2006. This complex and precise method of calculation load is very different from previous ways of calculating. A numerical example of industrial halls witth a crane is illustrated codified way of calculating such structures.
\end{abstract}

Key words: crane girder, load modeling, design procedure, Eurocode 


\section{Općenito}

Kod projektiranja industrijskih hala s kranovima, podatci o potrebnim slobodnim gabaritima u hali i tehnički podatci o kranu od ključne su važnosti za projektiranje cijele hale. Pritom postoje različite verzije izvedbe samog krana, odnosno načina njegovog povezivanja s konstrukcijom hale. Za veće se terete najčešće koriste tzv. mosni kranovi kod kojih se konstrukcija krana oslanja preko posebnih nosača (kranskih nosača) na stupove hale. Rade se i ovješene dizalice kod kojih su nosači krana ovješeni na konstrukciju hale, a postoje i neke druge izvedbe $s$ vlastitom konstrukcijom i sl. Mosni kranovi se uobičajeno rade u dvije izvedbe:

- kranovi koji se kreću po gornjoj pojasnici kranskih nosača (eng. Top running bridge cranes), slika 1

- kranovi koji se kreću po donjoj pojasnici kranskih nosača (eng. Underslung bridge crane).

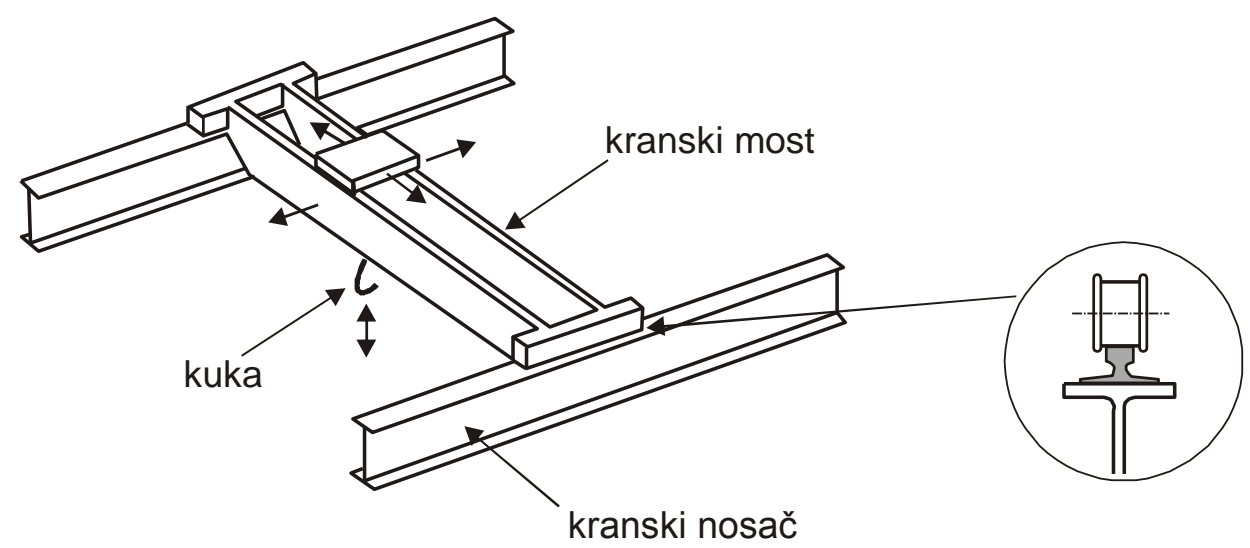

Slika 1 - Kran koji se kreće po gornjoj pojasnici kranskih nosača

Proračun kranskog nosača ima neke specifičnosti u odnosu na uobičajene konstrukcijske elemente hale pa tako treba razmatrati:

- kombinaciju poprečnih sila (zbog koncentriranih opterećenja) i momenata savijanja

- bočno-torzijsko izvijanje

- utjecaj bočnih (horizontalnih) opterećenja

- torzijska naprezanja zbog ekscentriciteta tračnice i horizontalnih sila

- kontrolu zamora i slično.

Dominantno opterećenje kranskog nosača je vertikalno, a iduće dominirajuće opterećenje je poprečno (horizontalno) djelovanje na kranski nosač. Opterećenje koje nastaje djelovanjem kranova ima statičku i dinamičku komponentu, a obje su u funkciji vremena i mijenjaju se ovisno o položaju krana i intezitetu tereta kojeg prenose i položaju tereta na kranskom mostu. Dinamičke sile koje nastaju pri pokretanju i zaustavljanju krana, podizanju tereta i poradi neravnosti tračnica, također ovise o vrsti krana i samoj izvedbi. Spomenuti dinamički utjecaji se u propisima uzimaju u obzir na način da se poznato statičko opterećenje množi odgovarajućim dinamičkim faktorima čija se vrijednost kreće od 1,0 do 2,0. Zakošenje krana pri kretanju rezultira bočnim opterećenjima, dok se pri pokretanju i zaustavljanju krana javljaju uzdužne sile. Branici na krajevima kranskih nosača moraju biti proračunati na preuzimanje udarne sile. Ostala opterećenja koja još treba uzeti u obzir su opterećenja nastala djelovanjem revizijskih staza i ovješenih penjalica, te strujnih vodova.

Jako je važno i ograničavanje maksimalnih vrijednosti progiba kako bi se izbjegli neželjeni dinamički efekti te osiguralo normalno funkcioniranje krana. Takvo ograničenje vertikalnih progiba kreće se oko L/700 za kranove srednje težine, dok se ograničenje horizontalnih (bočnih) pomaka kreće oko L/400 do L/600, [1]. Pritom se vertikalni progib uobičajeno ograničava na iznos manji od $25 \mathrm{~mm}$ kako bi se izbjegle prekomjerne vibracije.

Postavljanje ukrućenja na kranske nosače nešto većih visina povećava otpornost hrpta na izbočivanje, te povećava rotacijski kapacitet gornje pojasnice, odnosno sprječava njezino zakretanje. Međutim, poprečni su zavari slaba mjesta zbog efekta umaranja pa pri konstrukcijskom rješavanju detalja treba biti pažljiv. Tako se otpornost na zamor vlačne pojasnice može povećati ako se ugradi poprečno ukrućenje koje ne doseže do nje ili se na nju ne veže zavarivanjem. Treba spomenuti i problem zamora koji je kod kranskih nosača jako značajan, 
budući da su oni izloženi mnogostrukim ciklusima opterećenja i rasterećenja. Kritični detalji za zamor su spoj ukrućenja s pojasnicom, zatim spoj ukrućenja s hrptom te spoj pojasnice i hrpta. Vertikalni spregovi zgrade i kranskih nosača mogu biti izvedeni kao zajednički, pri čemu njihova pozicija može biti između stupova hale ili stupova kranske staze, ili se izvode zasebni vertikalni spregovi u pojedinim ravninama stupova. U uzdužnom smjeru, vertikalni spreg je najbolje pozicionirati na sredini između dilatacija kranskog nosača ili na sredini hale, zbog smanjenja nepovoljnih utjecaja temperature. Kranske tračnice moraju zažtititi gornju pojasnicu kranskih nosača od habanja te ravnomjerno raspodijeliti opterećenje uzrokovano kotačima krana na što veću kontaktnu širinu.

\section{Modeliranje opterećenja uslijed djelovanja kranova}

Dio Eurokoda 1 koji obrađuje opterećenja nastala djelovanjem kranova i ostalih strojeva nosi oznaku EN 1991-3 [2]. Opterećenja kranovima se općenito može razmatrati kao promjenjivo i kao izvanredno opterećenje pa su dani načini modeliranja za svaki od ta dva slučaja. Pri normalnim uvjetima korištenja opterećenje radom krana može se smatrati promjenjivim pa ono uključuje gravitacijska opterećenja, inercijske sile nastale zbog ubrzanja/usporavanja i zakošenja kranskog mosta, te ostale dinamičke utjecaje. Ti se utjecaji općenito mogu podijeliti na:

- $\quad$ promjenjiva vertikalna opterećenja uzrokovana vlastitom težinom krana i korisnim teretom

- promjenjiva horizontalna opterećenja uzrokovana ubrzavanjem/usporavanjem i zakošenjem pri kretanju, te ostale dinamičke utjecaje.

Dinamičke sile zbog vibracija i inercijskih sila pri djelovanju krana uzimaju se u obzir množenjem statičkih vrijednosti sila odgovarajućim dinamičkim faktorima $\varphi$ :

$$
F_{\varphi, k}=\varphi_{i} \cdot F_{k}
$$

gdje je:

$F_{\varphi, k}-$ karakteristična vrijednost opterećenja kranom

$\varphi_{i}$ - dinamički faktor

$F_{k}-$ karakteristična statička komponenta opterećenja kranom.

\section{Tablica 1 - Dinamički faktori}

\begin{tabular}{|c||l|l|}
\hline $\begin{array}{c}\text { DINAMIČKI } \\
\text { FAKTOR }\end{array}$ & \multicolumn{1}{|c|}{ UČINCI KOJI SE RAZMATRAJU } & \multicolumn{1}{|c|}{ PRIMJENJUJE SE NA } \\
\hline \hline$\varphi_{1}$ & Vibracijska pobuda konstrukcije krana zbog podizanja tereta s tla & Vlastitu težinu krana \\
\hline$\varphi_{2}$ & Dinamički učinak podizanja tareta od tla do krana & Teret koji se diže \\
\hline$\varphi_{3}$ & $\begin{array}{l}\text { Dinamički učinak naglog otpuštanja korisnog opterećenja ako se } \\
\text { koriste kliješta ili magnet }\end{array}$ & Teret koji se diže \\
\hline$\varphi_{4}$ & Dinamički učinci zbog kretanja po tračnicama ili kranskoj stazi & $\begin{array}{l}\text { Vlastitu težinu krana i teret } \\
\text { koji se diže }\end{array}$ \\
\hline$\varphi_{5}$ & $\begin{array}{l}\text { Dinamički učinci uzrokovani pogonskim silama i odnose se na } \\
\text { horizontalne sile (horizontalne uzdužne i poprečne), a koje se } \\
\text { pojavljuju prilikom kretanja ili kočenja krana po tračnicama }\end{array}$ & Vozne sile \\
\hline$\varphi_{6}$ & $\begin{array}{l}\text { Dinamički učinak zbog kretanja probnog tereta po kranskom mostu } \\
\text { koji se kreće }\end{array}$ & Probni teret \\
\hline$\varphi_{7}$ & Dinamički elastični učinak udarca na odbojnike & Sile u odbojniku \\
\hline
\end{tabular}

Mogućnost istovremenog djelovanja više nabrojanih opterećenja kranom uzima se u obzir na način da se formiraju određene skupine opterećenja, pa se svaka od tih skupina može smatrati jednim karakterističnim opterećenjem kranom koje se onda može kombinirati s ostalim vrstama (nekranskih) opterećenja. 
Tablica 2 - Skupine opterećenja i dinamički faktori koje treba uzeti u obzir za modeliranje djelovanja krana kao jednog karakterističnog opterećenja

\begin{tabular}{|c|c|c|c|c|c|c|c|c|c|c|c|}
\hline \multirow{3}{*}{ Djelovanje } & \multirow{3}{*}{ Oznaka } & \multicolumn{10}{|c|}{ Grupe opterećenja } \\
\hline & & \multicolumn{7}{|c|}{ GSN } & \multirow{2}{*}{$\begin{array}{l}\text { PROBNI } \\
\text { TERET } \\
8\end{array}$} & \multicolumn{2}{|c|}{ Izvanredno } \\
\hline & & 1 & 2 & 3 & 4 & 5 & 6 & 7 & & 9 & 10 \\
\hline Vlastita težina krana & $Q_{C}$ & $\varphi_{1}$ & $\varphi_{1}$ & 1 & $\varphi_{4}$ & $\varphi_{4}$ & $\varphi_{4}$ & 1 & $\varphi_{1}$ & 1 & 1 \\
\hline Teret koji se diže & $\mathrm{QH}_{\mathrm{H}}$ & $\varphi_{2}$ & $\varphi 3$ & - & $\varphi 4$ & $\varphi 4$ & $\varphi_{4}$ & ${ }^{*} \eta$ & - & 1 & 1 \\
\hline Ubrzanje kranskog mosta & $\mathrm{H}_{\mathrm{L}} \mathrm{i} \mathrm{H}_{\mathrm{T}}$ & $\varphi_{5}$ & $\varphi_{5}$ & $\varphi_{5}$ & $\varphi_{5}$ & - & - & - & $\varphi_{5}$ & - & - \\
\hline $\begin{array}{l}\text { Iskošenje kranskog mosta } \\
\text { pri kretanju }\end{array}$ & $\mathrm{H}_{\mathrm{s}}$ & - & - & - & - & 1 & - & - & - & - & - \\
\hline $\begin{array}{l}\text { Ubrzanje ili kočenje } \\
\text { mačke ili uređeja za } \\
\text { podizanje tereta }\end{array}$ & $\mathrm{H}_{\top 3}$ & - & - & - & - & - & 1 & - & - & - & - \\
\hline Vjetar pri radu & $\mathrm{FW}_{\mathrm{W}}^{*}$ & 1 & 1 & 1 & 1 & 1 & - & - & 1 & - & - \\
\hline Probni teret & $Q_{T}$ & - & - & - & - & - & - & - & $\varphi_{6}$ & - & - \\
\hline Sila na odbojnike & $\mathrm{H}_{\mathrm{B}}$ & - & - & - & - & - & - & - & - & $\varphi_{7}$ & - \\
\hline Sila prevrtanja & $\mathrm{H}_{\mathrm{TA}}$ & - & & & & & & & & & 1 \\
\hline
\end{tabular}

Pri određivanju vertikalnog opterećenja na kranski nosač zbog kretanja mačke po kranskom mostu, potrebno je analizirati različite položaje mačke (s i bez tereta) te na taj način pronaći minimalne i maksimalne vrijednosti vertikalnog opterećenja koje se modelira kao koncentrirana sila na mjestima kotača. Vertikalna opterećenja potrebno je povećati tako da se izmnože s odgovarajućim dinamičkim faktorima koji su prikazani u tablicama 1 i 2. Također treba voditi računa i o mogućem ekscentričnom djelovanju vertikalnog opterećenja.

Prema [2], preporuka je da se ekscentričnost uzme kao $25 \%$ od širine tračnice. Horizontalna opterećenja koja treba uzeti u obzir su:

- horizontalne sile koje nastaju zbog ubrzavanja i usporavanja kretanja kranskog mosta po tračnicama

- horizontalne sile koje nastaju zbog ubrzavanja i usporavanja kretanja mačke po kranskom mostu

- horizontalne sile koje nastaju zbog zakošenja pri kretanju kranskog mosta

- udarne sile u branike zbog kretanja krana

- udarne sile zbog kretanja mačke.

Od svih gore nabrojanih slučajeva opterećenja, samo se jedno uzima u obzir u pojedinoj skupini opterećenja prema tablici 2. Ostala opterećenja koja bi trebalo uzeti u obzir su:

- temperaturni utjecaji

- opterećenja revizijskih staza, platformi i ljestvi

- eksperimentalna (testna) opterećenja

- izvanredna opterećenja

- opterećenja od zamora.

\section{Numerički primjer}

Za ilustraciju primjene gore opisanih principa modeliranja opterećenja zbog djelovanja krana, obrađen je numerički primjer. Analizirano je opterećenje za nosač kranske staze statičkog sustava kontinuiranog nosača, izračunati su mjerodavni utjecaji, proveden je dokaz nosača kranske staze za granično stanje nosivosti i granično stanje uporabljivosti, te je izvršena i provjera umornosti za karakteristični detalj zavara između hrpta i pojasnice kranskog nosača. 
Za opsluživanje hale predviđena je dvogredna mosna dizalica s jednom kukom, nosivosti 12,5 t. Svaki par kotača ima zaseban pogonski motor. Ležajevi između pogona i nosača su za sva četiri kotača sustava nepokretno-nepokretno (IFF).

\section{Tablica 3 - Osnovni podatci o kranu}

\begin{tabular}{|l|c|}
\hline Nosivost krana & $Q_{h}=125,0 \mathrm{kN}$ \\
\hline Raspon krana & $\mathrm{L}=22,0 \mathrm{~m}$ \\
\hline Ukupna vlastita težina krana & $Q_{\mathrm{c}}=90,0 \mathrm{kN}$ \\
\hline Vlastita težina mačke & $\mathrm{G}_{\mathrm{c}}=7,80 \mathrm{kN}$ \\
\hline Brzina dizanja tereta & $\mathrm{V}_{\mathrm{h}}=5,0 \mathrm{~m} / \mathrm{min}$ \\
\hline Razmak kotača & $\mathrm{a}=2,50 \mathrm{~m}$ \\
\hline Klasa dizanja & $\mathrm{HC} 4$ \\
\hline Klasa umornosti & $\mathrm{S} 3$ \\
\hline Razmak od kuke do osi nosača kranske staze & $\mathrm{e}_{\min }=1,03 \mathrm{~m}$ \\
\hline
\end{tabular}

STATIČKI SUSTAV KRANSKOG NOSAČA

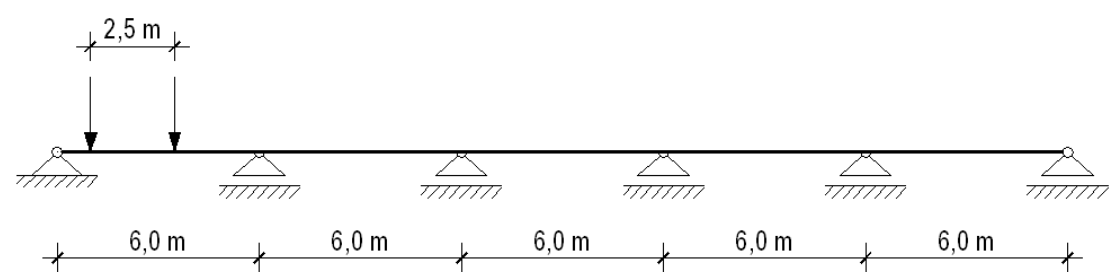

POPREČNI PRESJEK

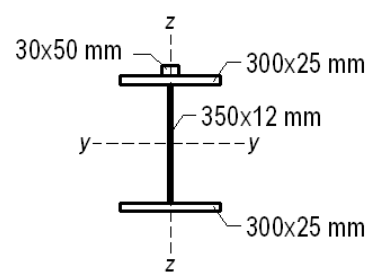

Slika 2 - Statički sustav i poprečni presjek nosača kranske staze

Tablica 4 - Podatci o poprečnom presjeku nosača kranske staze

\begin{tabular}{|c|c|}
\hline Površina presjeka & $\mathrm{A}=192,0 \mathrm{~cm}^{2}$ \\
\hline Visina presjeka & $\mathrm{h}=400 \mathrm{~mm}$ \\
\hline Širina pojasnice & $\mathrm{b}=300 \mathrm{~mm}$ \\
\hline Debljina pojasnice & $\mathrm{t}_{\mathrm{f}}=25 \mathrm{~mm}$ \\
\hline Debljina hrpta & $\mathrm{t}_{\mathrm{w}}=12 \mathrm{~mm}$ \\
\hline Debljina zavara & $\mathrm{a}=7 \mathrm{~mm}$ \\
\hline \multirow{2}{*}{ Momenti tromosti } & $\mathrm{I}_{\mathrm{y}}=57100 \mathrm{~cm}^{4}$ \\
\cline { 2 - 2 } & $\mathrm{I}_{\mathrm{z}}=11255 \mathrm{~cm}^{4}$ \\
\hline \multirow{3}{*}{ Momenti otpora } & $\mathrm{W}_{\mathrm{el}, \mathrm{y}}=2855 \mathrm{~cm}^{3}$ \\
\cline { 2 - 2 } & $\mathrm{W}_{\mathrm{el}, \mathrm{z}}=750,3 \mathrm{~cm}^{3}$ \\
\cline { 2 - 2 } & $\mathrm{W}_{\mathrm{pl}, \mathrm{y}}=3180 \mathrm{~cm}^{3}$ \\
\cline { 2 - 2 } & $\mathrm{W}_{\mathrm{pl}, \mathrm{z}}=1137,6 \mathrm{~cm}^{3}$ \\
\hline Torzijska konstanta & $\mathrm{I}_{\mathrm{t}}=332,7 \mathrm{~cm}^{4}$ \\
\hline Konstanta krivljenja & $\mathrm{I}_{\mathrm{w}}=3955078,1 \mathrm{~cm}^{6}$ \\
\hline
\end{tabular}

Proveden je proračun dinamičkih faktora $\left(\varphi_{1}, \varphi_{2}, \varphi_{3}, \varphi_{4}, \varphi_{5}\right)$ prema tablici 1 , a zatim analiza vertikalnog opterećenja za najmanje vrijednosti (kran neopterećen) i najveće vrijednosti (kran opterećen), vodeći računa 0 
ekscentričnom uvođenju vertikalnog opterećenja. Također su određeni i utjecaji horizontalnog opterećenja zbog pokretanja ili kočenja kranskog mosta, te zbog iskošenja kranskog mosta pri kretanju. Nakon izračuna mjerodavnih opterećenja, određene su skupine opterećenja kao karakteristične vrijednosti jednog promjenjivog djelovanja na kranski nosač (prema tablici 2), a konačni rezultati su dani u tablici 5.

Tablica 5 - Skupine opterećenja kao karakteristične vrijednosti jednog djelovanja na kran

\begin{tabular}{|c|c|c|c|c|c|c|c|c|}
\hline \multirow{9}{*}{ 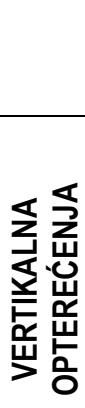 } & \multirow{6}{*}{$\begin{array}{c}\text { VLASTITA } \\
\text { TEŽINA KRANA }\end{array}$} & \multirow{4}{*}{$Q_{r(\min )}$} & & \multicolumn{5}{|c|}{ SKUPINE OPTEREĆENJA [ kN ] } \\
\hline & & & & \multirow{2}{*}{$\frac{1}{26,69}$} & \multirow{2}{*}{$\frac{2}{26,69}$} & \multirow{2}{*}{$\frac{3}{24,27}$} & \multirow{2}{*}{$\frac{4}{24,27}$} & \multirow{2}{*}{ 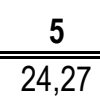 } \\
\hline & & & $\gamma=1,0$ & & & & & \\
\hline & & & $\gamma=1,35$ & 36,03 & 36,03 & 32,76 & 32,76 & 32,76 \\
\hline & & \multirow{2}{*}{$Q_{r, \min }$} & $\gamma=1,0$ & 22,81 & 22,81 & 20,73 & 20,73 & 20,73 \\
\hline & & & $\gamma=1,35$ & 30,79 & 30,79 & 27,99 & 27,99 & 27,99 \\
\hline & \multirow{4}{*}{$\begin{array}{c}\text { VLASTITA } \\
\text { TEŽINA KRANA + } \\
\text { TERET DIZANJA }\end{array}$} & \multirow{2}{*}{$Q_{r, \max }$} & $\gamma=1,0$ & 101,76 & 86,27 & & 82,84 & 82,84 \\
\hline & & & $\gamma=1,35$ & 137,38 & 116,46 & & 111,83 & 111,83 \\
\hline & & \multirow{2}{*}{$Q_{r(\max )}$} & $\gamma=1,0$ & 26,49 & 25,73 & & 23,66 & 23,66 \\
\hline & & & $\gamma=1,35$ & 35,76 & 34,74 & & 31,94 & 31,94 \\
\hline \multirow{12}{*}{ 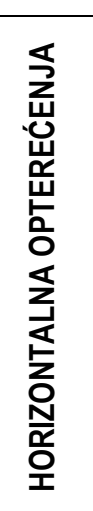 } & \multirow{8}{*}{$\begin{array}{l}\text { POKRETANJE I } \\
\text { KOČENJE }\end{array}$} & \multirow{2}{*}{$\mathrm{H}_{\mathrm{L}, 1}$} & $\gamma=1,0$ & 6,22 & 6,22 & 6,22 & 6,22 & \\
\hline & & & $\gamma=1,35$ & 8,40 & 8,40 & 8,40 & 8,40 & \\
\hline & & \multirow{2}{*}{$\mathrm{H}_{\mathrm{L}, 2}$} & $\gamma=1,0$ & 6,22 & 6,22 & 6,22 & 6,22 & \\
\hline & & & $\gamma=1,35$ & 8,40 & 8,40 & 8,40 & 8,40 & \\
\hline & & \multirow{2}{*}{$\mathrm{H}_{\mathrm{T}, 1}$} & $\gamma=1,0$ & 6,74 & 6,74 & 6,74 & 6,74 & \\
\hline & & & $\gamma=1,35$ & 9,10 & 9,10 & 9,10 & 9,10 & \\
\hline & & \multirow{2}{*}{$\mathrm{H}_{\mathrm{T}, 2}$} & $\gamma=1,0$ & 23,9 & 23,9 & 23,9 & 23,9 & \\
\hline & & & $\gamma=1,35$ & 32,27 & 32,27 & 32,27 & 32,27 & \\
\hline & \multirow{4}{*}{$\begin{array}{l}\text { ISKOŠENJE } \\
\text { KRANA PRI } \\
\text { KRETANJU }\end{array}$} & \multirow{2}{*}{$\mathrm{H}_{\mathrm{s}, 1, \mathrm{~T}}$} & $\gamma=1,0$ & & & & & 9,58 \\
\hline & & & $\gamma=1,35$ & & & & & 12,93 \\
\hline & & \multirow{2}{*}{$H_{\mathrm{s}, 2, \mathrm{~T}}$} & $\gamma=1,0$ & & & & & 9,58 \\
\hline & & & $\gamma=1,35$ & & & & & 12,93 \\
\hline
\end{tabular}

Proračun reznih sila je proveden kompjutorski programom „Autodesk Robot Structural Analysis“. Mjerodavni dijagrami unutarnjih sila prikazani su na slikama 3, 4, 5 i 6 .

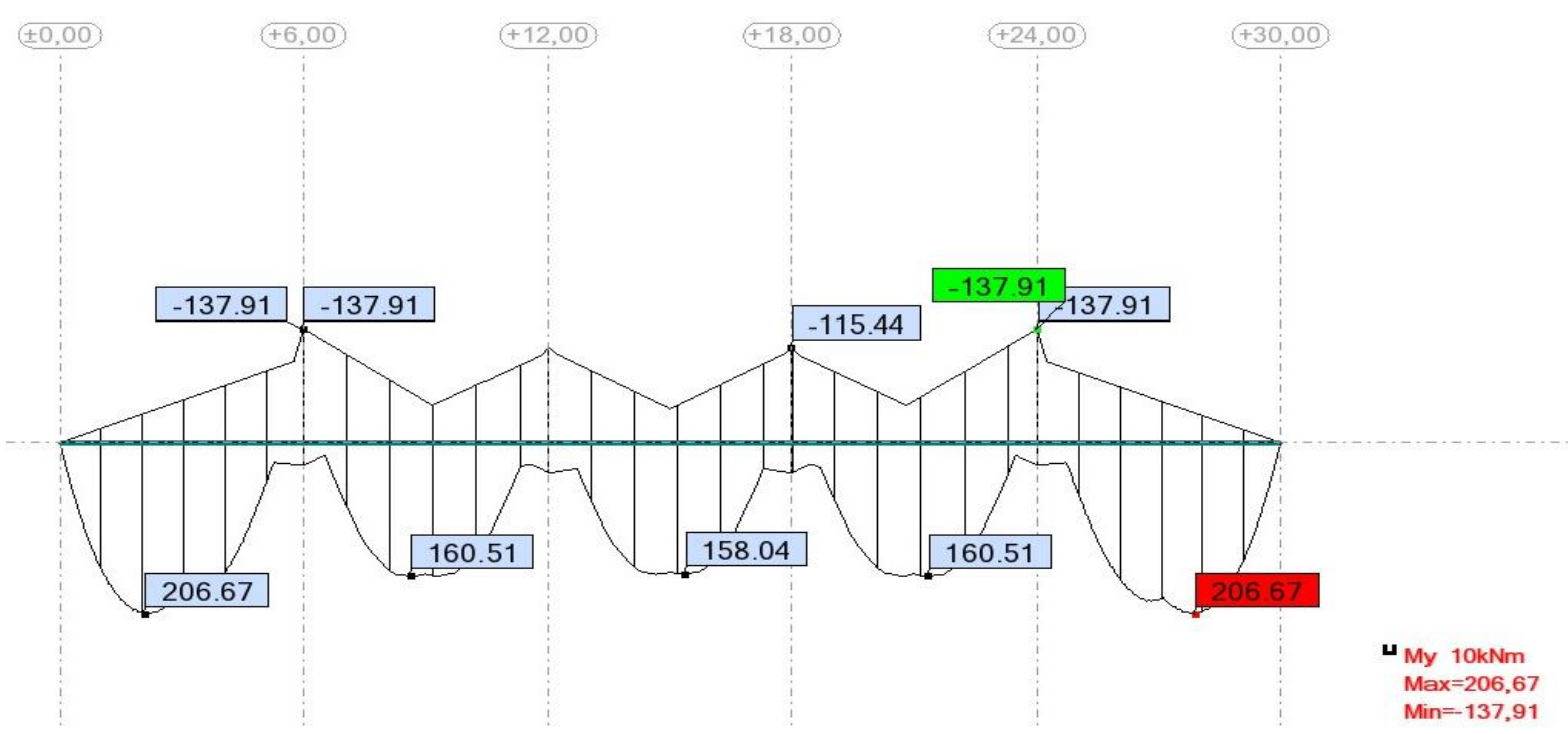

Slika 3 - Anvelopa momentnog dijagrama $M_{y, E d}$ (skupina opterećenja 1, najveći moment oko jače osi $M_{y, E d}$ uslijed $Q_{r, \text { max }}$ 


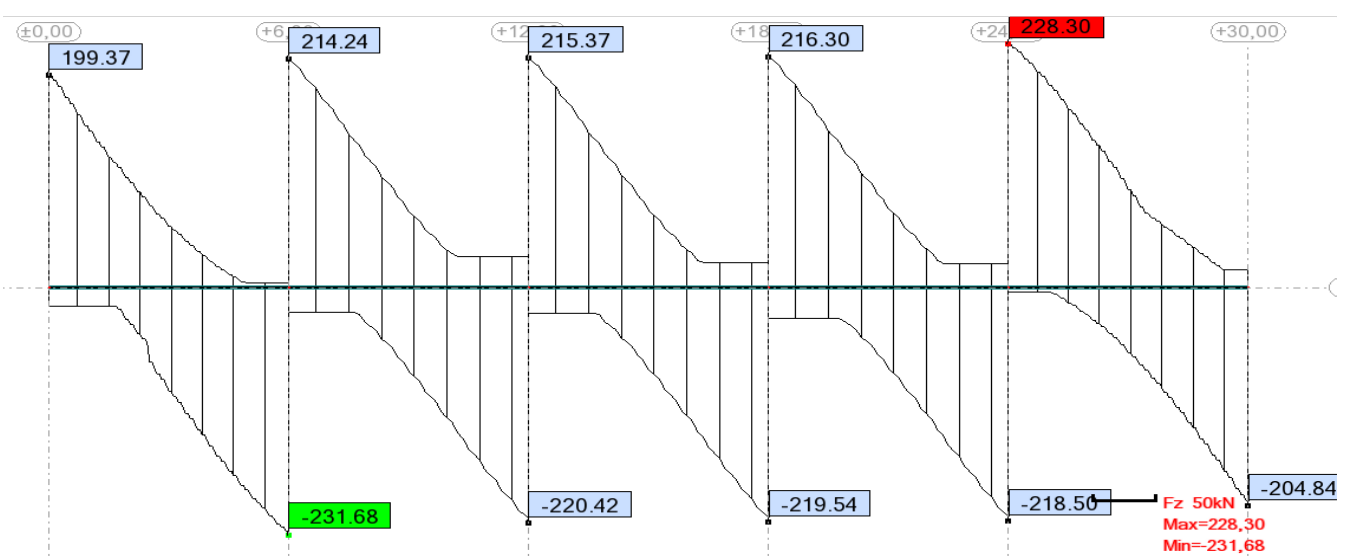

Slika 4 - Anvelopa poprečnih sila $V_{z, E d}$ (skupina opterećenja 1 , najveća poprečna sila $V_{z, E d)}$

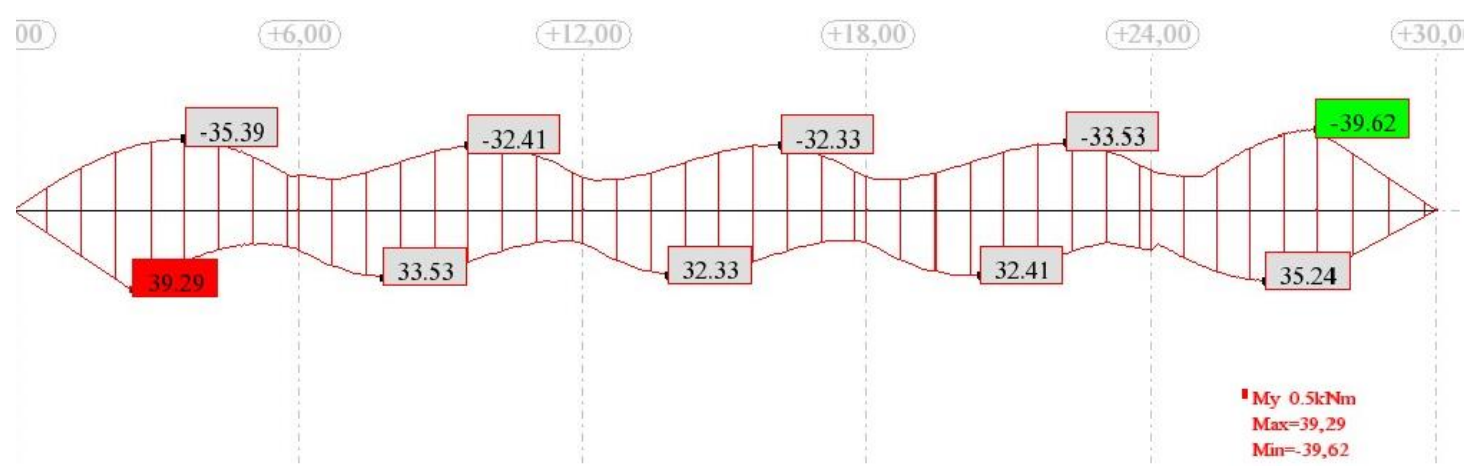

Slika 5 - Anvelopa momenata savijanja oko slabije osi $M_{z, E d}$ (skupina opterećenja 1, najveći moment oko slabije osi $\mathrm{M}_{\mathbf{z}, \mathrm{Ed}}$ )

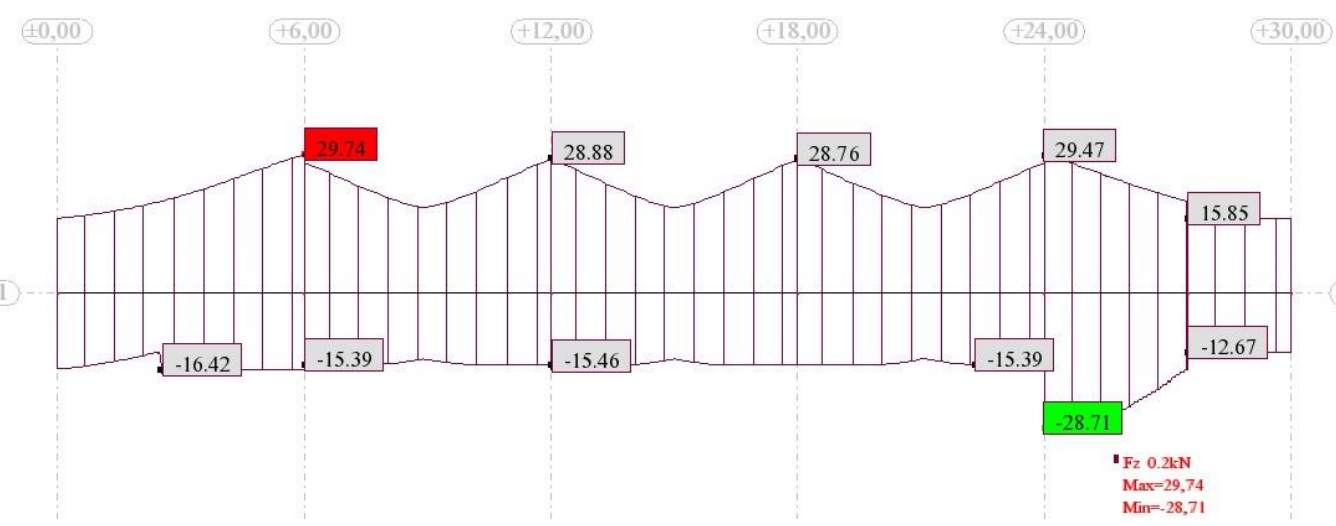

Slika 6 - Anvelopa poprečnih sila $\mathrm{V}_{\mathrm{y}, \mathrm{Ed}}$ (skupina opterećenja 1, najveća poprečna sila $\mathrm{V}_{\mathrm{y}, \mathrm{Ed}}$ )

Dio Eurokoda 3 koji obrađuje problematiku konstrukcija s kranovima nosi oznaku EN 1993-6, [3]. Za mjerodavne rezne sile napravljeni su dokazi pouzdanosti nosača kranske staze za granično stanje nosivosti i granično stanje uporabljivosti te provjera zamora prema [4], [5] i [6]. Zbog ograničenja veličine ovog rada ovdje se samo navode provedeni dokazi i prikazuju konačni rezultati proračuna, tablica 6 , a detaljni postupak može se pogledati u [7]. Dokaz nosača kranske staze za granično stanje nosivosti sastoji se od:

- klasifikacije poprečnog presjeka

- dokaza otpornosti hrpta na poprečne sile

- dokaza gornjeg pojasa na posmik

- dokaza na kombinirani posmik iz savijanja i torzije 
- dokaza na savijanje zbog iskošenja krana pri kretanju uz uzdužnu silu

- dokaza na bočno torzijsko izvijanje

- dokaza hrpta na "crippling" zbog koncentriranog opterećenja

- dokaza zavara na spoju hrbat - pojasnica.

Dokaz nosača kranske staze za granično stanje uporabljivosti sastoji se od:

- dokaza progiba zbog vertikalnog opterećenja

- dokaza progiba zbog horizontalnog opterećenja.

Procjena zamora sastoji se od:

- $\quad$ proračuna ekvivalentnog opterećenja za klasu umornosti S3

- postupka procjene umornosti zavara između hrpta i gornje pojasnice za normalna i posmična naprezanja te interakcije tih naprezanja.

Tablica 6 - Rezultati proračuna za GSN, GSU i procjenu umornosti

\begin{tabular}{|c|c|c|}
\hline \multicolumn{3}{|c|}{ GSN - granično stanje nosivosti } \\
\hline KRITERIJ & DJELOVANJE & OTPORNOST \\
\hline Dokaz otpornosti na savijanje oko jače osi & $M_{y, E d}=206,67 \mathrm{kNm}$ & $M_{p l, y, R d}=874,50 \mathrm{kNm}$ \\
\hline Dokaz otpornosti na savijanje oko slabije osi & $M_{z, E d}=39,62 \mathrm{kNm}$ & $M_{p l, z, R d}=312,84 \mathrm{kNm}$ \\
\hline Dokaz otpornosti hrpta na poprečne sile & $V_{z, E d}=231,68 \mathrm{kN}$ & $V_{p l, z, R d}=800,21 \mathrm{kN}$ \\
\hline Dokaz gornjeg pojasa na posmik & $V_{y, E d}=29,74 k N$ & $V_{p l, y, R d}=1190,78 \mathrm{kN}$ \\
\hline $\begin{array}{l}\text { Dokaz na poprečnu silu uzimajući u obzir } \\
\text { utjecaj torzije }\end{array}$ & $V_{z, E d}=231,68 \mathrm{kN}$ & $V_{p l, T, R d}=764,54 \mathrm{kN}$ \\
\hline $\begin{array}{l}\text { Dokaz na savijanje zbog iskošenja krana pri } \\
\text { kretanju uz uzduzznu silu }\end{array}$ & $\frac{N_{E d}}{\frac{A \times f_{y}}{\gamma_{M 1}}}+\frac{M_{\Phi, y, E d}}{\frac{W_{p l, y} \times f_{y}}{\gamma_{M 1}}}+\frac{M}{\alpha_{L T} \times}$ & $+\frac{\sigma_{\Phi, w, E d}}{\alpha_{L T} \times \frac{f_{y}}{\gamma_{M 1}}}=0,549<1,0$ \\
\hline Dokaz na bočno torzijsko izvijanje & \multicolumn{2}{|c|}{ Element nije osjetljiv na bočno torzijsko izvijanje } \\
\hline $\begin{array}{l}\text { Dokaz hrpta na "crippling" zbog } \\
\text { koncentriranog opterećenja }\end{array}$ & $F_{E d}=137,38 \mathrm{kN}$ & $R_{w, R d}=331,30 \mathrm{kN}$ \\
\hline Dokaz zavara na spoju hrbat - pojasnica & $\sigma_{E d}=20,33 \mathrm{kN} / \mathrm{cm}^{2}$ & $\sigma_{w, R d}=23,37 \mathrm{kN} / \mathrm{cm}^{2}$ \\
\hline \multicolumn{3}{|c|}{ GSU - granično stanje uporabljivosti } \\
\hline KRITERIJ & UKUPNI PROGIB & DOPUŠTENI PROGIB \\
\hline Dokaz progiba zbog vertikalnog opterećenja & $w_{\max }=0,42 \mathrm{~cm}$ & $w_{d o p}=1,0 \mathrm{~cm}$ \\
\hline Dokaz progiba zbog horizontalnog opterećenja & $w_{\max }=0,18 \mathrm{~cm}$ & $w_{\text {dop }}=1,0 \mathrm{~cm}$ \\
\hline \multicolumn{3}{|c|}{ PROCJENA ZAMORA ZAVARA IZMEĐU HRPTA I GORNJE POJASNICE } \\
\hline KRITERIJ & \multicolumn{2}{|c|}{ DOKAZ POUZDANOSTI } \\
\hline Normalna naprezanja & \multicolumn{2}{|c|}{$\frac{\gamma_{F f} \cdot \Delta \sigma_{E, 2}}{\Delta \sigma_{C} / \gamma_{M f}}=0,72<1,0$} \\
\hline Posmična naprezanja & \multicolumn{2}{|c|}{$\frac{\gamma_{F f} \cdot \Delta \tau_{E, 2}}{\Delta \tau_{C} / \gamma_{M f}}=0,37<1,0$} \\
\hline Interakcija normalnih i posmičnih naprezanja & \multicolumn{2}{|c|}{$\left(\frac{\gamma_{F f} \cdot \Delta \sigma_{E, 2}}{\Delta \sigma_{C} / \gamma_{M f}}\right)^{3}+\left(\frac{\gamma_{F f} \cdot \Delta \tau_{E, 2}}{\Delta \tau_{C} / \gamma_{M f}}\right)^{5}=0,38<1,0$} \\
\hline
\end{tabular}




\section{Zaključak}

U radu je opisan način modeliranja opterećenja zbog djelovanja krana prema [2] i [3] koji je složenošću i preciznošću u izračunu djelovanja različit u odnosu na dosadašnje načine proračuna. Opisane su vrste opterećenja koja mogu nastati prilikom djelovanja krana, te još neke specifičnosti dijelova industrijskih hala $\mathrm{s}$ kranovima. U numeričkom primjeru obrađene su sve potrebne analize prema navedenim normama, a paralelno je pojašnjen i postupak proračuna. Za dobivena mjerodavna opterećenja određene su skupine opterećenja kao karakteristične vrijednosti jednog djelovanja na kranski nosač. Nakon određivanja reznih sila proveden je dokaz pouzdanosti nosača kranske staze za granično stanje nosivosti, granično stanje uporabljivosti te procjena zamora. U radu su dani samo važniji međurezultati zbog obimnosti cijelog proračuna koji nije mogao biti cjelovito prikazan.

\section{Literatura}

[1] Markulak, D.: Posebna poglavlja čeličnih konstrukcija; Sveučilište J.J. Strossmayera u Osijeku, Građevinski fakultet Osijek, Osijek, 2010.

[2] HRN EN 1991-3:2008 Eurokod 1 - Djelovanja na konstrukcije - 3. dio: Djelovanja prouzročena kranovima i strojevima (EN 1991-3:2006), Hrvatski zavod za norme, Zagreb, 2008.

[3] HRN EN 1993-6:2008 Eurokod 3 - Projektiranje čeličnih konstrukcija - 6. dio: Kranske staze (EN 19936:2007), Hrvatski zavod za norme, Zagreb, 2008.

[4] HRN EN 1993-1-1:2008 Eurokod 3 - Projektiranje čeličnih konstrukcija - Dio 1-1: Opća pravila i pravila za zgrade (EN 1993-1-1:2005+AC:2006), Hrvatski zavod za norme, Zagreb, 2008.

[5] HRN EN 1993-1-9:2008 Eurokod 3 - Projektiranje čeličnih konstrukcija - Dio 1-9: Zamor (EN 1993-19:2005+AC:2005), Hrvatski zavod za norme, Zagreb, 2008.

[6] Androić, B.; Dujmović, D.; Džeba, I.: Metalne konstrukcije 4, IA projektiranje, Zagreb, 2003.

[7] Joketović, M.: Proračun čelične hale s kranskim nosačem, diplomski rad, Sveučilište J.J. Strossmayera u Osijeku, Građevinski fakultet Osijek, Osijek, 2011. 